\title{
Correlation Analytics of Blue-Collar Employees' Organizational Levels in Coal Mining*
}

\author{
H. Tezcan Uysal, Emel Kesim \\ Department of Management and Organization, Zonguldak Vocational High School, Bülent Ecevit University, \\ Zonguldak, Turkey \\ Email: h.tezcanuysal@hotmail.com
}

Received 26 December 2014; accepted 15 January 2015; published 20 January 2015

Copyright (C 2015 by authors and Scientific Research Publishing Inc.

This work is licensed under the Creative Commons Attribution International License (CC BY). http://creativecommons.org/licenses/by/4.0/

(C) (7) Open Access

\begin{abstract}
The aims of this study are determining the organizational burnout, organizational commitment and job performance levels of the employees that work in coal mining and finding out the influences of these levels upon each other. In accordance with this purpose, a study, which is aimed at blue-collar workers that work within the facilities of Turkish Hard Coal Enterprise (TTK)-Turkey's biggest coal operation, was carried out. Survey technique was used in this study, and the prepared questionnaires were conducted to 1238 blue-collar workers through face-to-face method. Maslach's "Maslach Burnout Inventory" and Allen and Meyer's "Organizational Commitment Scale" were taken as bases in the preparation of these questionnaires. The data obtained in the research was analyzed through correlation and regression analyses, one-way analysis and independentsamples T-test. In the result of the analyses carried out, a significant relation was not found between the organizational commitment and the organizational burnout levels and between the organizational commitment and the job performances of blue-collar workers, while it was determined that 1 unit of increase in organizational burnout level caused 0.460 unit of decrease in job performance. However, the determination of both high organizational burnout and high worker performance in the same TTK organization was interpreted as the development of organizational burnout based on performance, which is rarely seen in the literature.
\end{abstract}

\section{Keywords}

Work Psychology, Coal Mining, Blue-Collar Worker, Organizational Burnout, Job Performance, Organizational Commitment

\footnotetext{
"Turkish Hard Coal Enterprise is an operation with the mission of evaluating the national hard coal reserves with the cheapest cost possible, in a way to give the least harm to environment in accordance with the general industry and energy policies of the government and bringing them in the national economy, and the vision of increasing production and productivity by using advanced and new technologies in coal mining, bringing down costs, meeting the need of hard coal in the industry of Turkey, especially for the Iron-Steel sector.
} 


\section{Introduction}

Open system organizations are affected by the changes in courses of live. In the result of this response, arising from internal and external factors, organizational changes of the people in the organization are absolute. Rather than the external factors, changes in the organization cause more active changes on individuals that form the organizational structure. Factors such as working places, manners and states of the workers affect these changes experienced in the organization in different levels. Especially the response probability is high for the employees that work in coal mining, an area where physical power is used intensely, performance criteria are high and organizational climate is degenerated. Naturally, the imposed effects create fluctuations in the burnout and commitment levels of the employees, so they cause decreases in performance that are debilitative for the performance policies in coal mining.

The aims of this study are determining the organizational burnout, organizational commitment and job performance levels of the employees that work in coal mining and finding out the influences of these levels upon each other. In accordance with this purpose, a study, which is intended for blue-collar workers that work within the facilities of Turkish Hard Coal Enterprise that has Turkey's biggest production capacity in coal mining, will be carried out. This study, where blue-collar workers under a work load increasing based on the heavy working conditions and the corporation strategies in coal mining are analyzed, is important due to there is not any preceding study in the field with regards to the variables analyzed, and with regards to the determination of inhouse organizational erosion and preparing and carrying out the structural works intended for this erosion. In addition, it has an importance also with regards to comparison of organizational levels of the employees that work in coal mines that are in service in different parts of the world and show alterations with regards to working conditions, job security and rates of occupational accidents.

\section{Coal Mining and Turkish Hard Coal Authority}

As a fossil fuel, coal is used as an energy source for hundreds of years. It is known that the international trade of coal goes back to the period of Roman Empire. Coal commenced industrial revolution in the 19th Century and electric era in the 20th Century. It maintained its importance as the primary source of energy of the world until 1960s, gave its place to petrol towards the end of 60s; however, regained its significance in world's energy agenda when its importance was understood in electricity production [1]. In our day, coal is one of the world's most plentiful energy resources, and its use is likely to quadruple by the year 2020 [2].

Coal is a kind of mineral and/or rock that composed of carbon, hydrogen and oxygen; involves in small quantities of inorganic compounds and mineral matters that generate sulphur and nitrogen; and has special chemical and physical structures. Coals obtained from collieries are separated into two classes. The first one is Hard Coal, and the second one is Brown Coal. Coal mining is carried out by TTK* in Zonguldak Hard Coal Field. The complex geological structure of Zonguldak Hard Coal Field, where deep underground coal mining is carried out, prevents a complete mechanization, and hard coal production is realized in a labor-intensive structure to a great extent [3] (TTK, 2013). However, an increasing amount of hard coal is imported every year due to its production is not sufficient [4].

There are many factors that may affect the health of mineworker such as firedamp explosion, ventilation, dust, noise, vibration, manual handling, electric shock, insufficient lighting, hygiene and psychological problems. For minimizing these factors, TTK made important improvements in the field of work safety through the projects like work safety enhancement project, training project, OHSAS 18001 (International Occupational Health and Safety Standard) and the project of constituting work security and safety standard. In our day, it is seen that these enhancements are not sufficient for preventing mining accidents. Particularly the need for intensive labor force in the production of hard coal increases the risk of accident. This creates a negative effect in the working psychologies of mineworkers and causes deteriorations in their organizational levels and it was propounded in a study carried out in TTK. Korkmaz [5] (2011) researched the relation between occupational accidents and efficiency and determined that the increase in the number of workers who were injured or died affected the moods and motivations of the workers negatively and this created a negative effect on labor productivity.

Occupational accidents are naturally the main factor that affects the working psychologies of mineworkers. However, here the basic question is the source of occupational accidents: do they arise from intense production or negligence? At this point, the best way is a worldwide examination of occupational accidents experienced in coal mines. In Table 1, there are three countries that produce hard coal. When death rates per million tons of 
Table 1. Number of deaths per million tons of hard coal production.

\begin{tabular}{cccc}
\hline Year & Turkey & China & USA \\
\hline 2005 & 5.5 & 2.7 & 0.01 \\
2006 & 2.5 & 2.0 & 0.06 \\
2007 & 8.0 & 1.5 & 0.04 \\
2008 & 7.2 & 1.2 & 0.02 \\
2009 & 7.3 & 1.1 & 0.03 \\
2010 & 7.1 & 1.0 & 0.02 \\
2011 & 7.0 & 1.3 & 0.01 \\
2012 & 7.2 & 1.2 & 0.02 \\
\hline
\end{tabular}

hard coal production are analyzed, it is seen that the death rate in Turkey in the result of the occupational accidents in hard coal production was 6 times bigger than China and 360 times bigger than the USA. Death rates to be this much high in Turkey, which has only $0.3 \%$ of the world hard coal reserves, shows that the occupational accidents arises from lacking hardware and insufficient work safety, rather than intense production. And the workers in coalmine go down the ground every day despairingly by knowing this and continue working with no confidence. TTK's policy of high performance with relevant cost triggers this process as well.

\section{Organizational Levels}

\subsection{Organizational Burnout}

The burnout syndrome took part in the literature for the first time by being used by Herbert J. Freudenberger in 1974 [6]. He defined burnout syndrome as a state of mental and physical exhaustion caused by one's professional life [7]. Maslach and Jackson [8] identified organizational burnout as a physical and mental syndrome that involved negative attitudes shown by people against their jobs, lives and other people with the states of physical exhaustion, long time tiredness, desperation and hopelessness. Sarros and Densten [9] defined burnout as a maladaptive coping mechanism to working conditions that were stressful, demanding, or lacking sufficient challenge and recognition [10]. And Pines \& Aronson [11] defined burnout as a state of physical, emotional and mental exhaustion caused by long-term involvement in situations that were emotionally demanding [12]. But today, the most widely adopted definition for the "burnout" concept is the one identified by Christiba Maslach, who developed Maslach Burnout Inventory (MBI).

The burnout concept has three sub-dimensions of emotional exhaustion, depersonalization and lacking of personal achievement [13]. While Freudenberger dealt with the emotional exhaustion dimension of burnout, Maslach and Jackson analyzed all three dimensions. These dimensions were summarized below.

-Emotional Exhaustion: Exhaustion is the fundamental stress component of burnout representing a feeling of energy loss and a sense of being completely drained out of emotional and physical strength [14]. Conceptually, emotional exhaustion refers to chronic feelings of being overwhelmed and worn out because of one's work [15].

-Depersonalization: Paris and Hoge [16] defined depersonalization as an unfeeling and impersonal response toward recipients of one's service, care, treatment, or instruction. In other words, depersonalization refers to an impersonal and dehumanized perception of recipients, characterized by a callous, negative, and detached attitude [17]. This depersonalization gives rise to feelings of reduced personal accomplishments. Thus, job burnout process starting from emotional exhaustion ends at personal accomplishments through depersonalization [18].

-Reduced Personal Accomplishment is a decline in an individual's feeling of competence and productivity within the work environment [19]. Personal accomplishment refers to a decline in one's feelings of competence and successful achievement in one's work with people [20]. Reduced personal accomplishment or feelings of inefficacy are prompted by a work situation with chronic, overwhelming demands that erodes one's sense of effectiveness [21].

Whereas emotional exhaustion and depersonalization are positively related to burnout, personal accomplishment is negatively related to burnout [22]. High levels of emotional exhaustion and depersonalization and low 
levels of personal accomplishment engender burnout [23].

\subsection{Organizational Commitment}

One of the primary purposes of operations is getting more efficiency from employees by enhancing their skills and increasing their organizational commitment [24]. Affected by the factors such as fairness, satisfaction, job security, organizational communication, worker engagement and reliance to employees within the operation [25], the organizational commitment is also influenced by the factors such as self determination, support from workfellows and manager/major, promotion, honouring by society, occupational hazard, routine and stress [26].

Cook \& Wall [27] identified organizational commitment as the emotional response shown by people to properties of the organization where they work. Meyer et al. [28] developed "Three Dimensional Commitment Measure" consisting of continuance, emotional and normative commitment, and represented organizational commitment through these dimensions. O’Driscoll and Randall [29] described continuance commitment as a loyalty depending on the thought of bearing the cost in case of leaving of employment. Commeiras and Fournier [30] identified it as an obligation for employees arising from the costs related to leaving from organization. And emotional commitment is the dependence to organization with emotions like loyalty and love [31], in other words, it is the recognition of organizational aim, values and a strong faith along with the desire of maintaining the membership of the organization [32]. And the last commitment dimension is the normative commitment. This type of commitment is the obligation felt by employees to organization basing on personal values and norms [33] and as a result of the socialization in culture, employees to devote themselves to organization and their loyalty to corporation [34].

Allen and Mayer [35] expressed the commitment types in three dimensional commitment measure as the following: employees with strong emotional commitment stay in the organization because they want to do this; employees with strong normative commitment stay in the organization because they ought to do this; employees with strong continuance commitment stay in the organization because they need to do this.

\subsection{Job Performance}

Job performance is an important factor in organizational practice and research [36]. Because it acts the main role in most personnel decisions such as merit-based compensation, promotion and retention of employees [37]. Especially nowadays, in order to be competitive in a rapidly changing economic and working environment, increasing job performance of employees and consequently the performances of companies has become more crucial [38].

Borman and Motowidlo [39] identified two types of employee behaviour that are necessary for organizational effectiveness: task performance and contextual performance [40]. Task performance refers to an individual's proficiency with which he or she performs activities that contribute to the organization's "technical core" [41]. In other words, task performance is an indicator of an employee's talents, capability, and competence [42]. And contextual performance is defined as "behavioral patterns that support the psychological and social context in which task activities are performed" [43]. Contextual activities are important because they contribute to organizational effectiveness in ways that shape the organizational, social, and psychological context that serves as the catalyst for task activities and processes [44].

Employees working in manufacturing companies exert different levels, frequencies, and durations of the physical effort during performing their jobs [45]. Although their job performances depend on the collaboration and communication with co-workers [46], uncongenial workplace environment such as noisy (much on unfamiliar sound), too low or high temperature, stuffy office, lack of natural light or even cramped working space may affect their job performance [47].

\subsection{Literature Review Related to Organizational Level}

Coal mining is one of the most preferred sectors by people to work. However, considering heavy working conditions, coal mining is also seen as a sector that carries risk in terms of worker health and job security. Our work focused on this dilemma and it was planned to make a research intended for organizational burnout, performances and commitment levels of employees working under heavy conditions. Some of the studies that take part in the literature related to the variables to be analyzed are as the following. 
In a study they performed in Mpumalanga, Mclaggan, Bezuidenhout \& Botha [48] analyzed leadership style and organizational commitment in a labor organization working in coal mining and found a positive relation between these two variables. In a study where they analyzed the relation between organizational burnout and occupational accidents in coal mining, Kowalski \& Podlesny [49] carried out a research aimed at 154 employees and in conclusion, they determined that the occupational accidents encountered in mine caused moderate organizational burnout. Talachi \& Gorji [50] carried out a research on 12 workers, who work in coal mining, about burnout and work satisfaction and determined a negative relation between their organizational burnout and work satisfaction. In the study they performed on 85 workers who work in coal mining in Indonesia, Yusuf et al. [51] analyzed job performance and in the result of the study, they determined that organizational learning culture and organizational citizenship behaviour affected job performance positively. In a study they carried out, Meyer et al. [52] performed an application aimed at first level managers in a catering company, and in conclusion, they found a positive relation between job performance and emotional commitment. In a research carried out by Salehi \& Gholtash [53] by using Maslach and Jackson's Maslach Burnout Inventory and Allen and Mayer's commitment measure, it was determined that burnout levels of employees affected their organizational commitment. Güneş, Bayraktaroğlu \& Kutanis [54] realized a research by using Maslach Burnout Inventory and found a negative relation between burnout levels and organizational commitments of employees. In their study, Marmaya et al. [55] performed an analysis of affective commitment, continuance commitment and normative commitment, which are three sub-dimensions of organizational commitment, and organizational burnout upon 50 employees, and in the result of this study, they found that the affective commitment dimension of organizational commitment was the only one that affects organizational burnout. In the research they realized by using the sub-models of organizational burnout, Cropanzano, Rupp \& Byrne [56] found a significant and negative relation between emotional burnout and job performance.

According to some researchers in the field of organizational behaviour, there is a permanent existence of a positive relation between job performance and organizational commitment [52]. However, some researchers in the literature put forth some findings on the contrary of this belief. One of them is the study made by Yiing \& Ahmad [57]. Researching the effects of organizational culture in the relation between organizational commitment, job satisfaction and performance and the relation between leadership behaviour and organizational commitment, writers could not determine a significant relation between organizational commitment and job performance in the result of the research they did on 283 Malaysian people. The writers could not determine a positive relation between job performance and organizational commitment in the literature, and stated that the existing commitment and performance was due to economic conditions, absence of alternative jobs and psychology of unemployment.

\section{Research Design and Methodology}

\subsection{Purpose of the Study}

The aims of the study are determining the organizational burnout, job performance and organizational commitment levels of the underground and above ground workers who work in coal mining, and finding out the effects of the levels upon each other. In line with these purposes, a research was conducted intended for blue-collar employees who work in the facilities of Turkish Hardcoal Enterprise (TTK).

\subsection{Data Gathering Method and Hypotheses of the Research}

Quota sampling, which is one of the non-stochastic research methods, was used in the research and it was implemented on 1238 blue-collar workers. Questionnaire technique was used in the study and the questionnaires prepared were applied to intended population through face-to-face method. 5-point likert type scales were used in the questionnaire. Maslach Burnout Inventory, which was developed by Maslach and is commonly used in this field, was taken as basis in the questionnaire for the determination of burnout level, and according to the features of the sample it was made changes on the scale and the number of questions were decreased. Allen and Meyer's "Organizational Commitment Scale" was taken as basis for the determination of commitment level, and the scale was rearranged according to the features of the sample and the questions fit for the purpose of the research were added. Employee classification in coal mining was used in the research and the hypotheses developed according to that were stated below. 


\section{Hypotheses Intended for Casual Workers;}

$\mathbf{H}_{\mathbf{1}}$ : There is a significant relation between organizational burnout and job performance of casual workers.

$\mathbf{H}_{\mathbf{b}}$ : There is a significant relation between organizational burnout and organizational commitment of casual workers.

$\mathbf{H}_{\mathbf{1}}$ : There is a significant relation between organizational commitment and job performance of casual workers.

Hypotheses Intended for Technical Staff;

$\mathbf{H}_{\mathbf{1 e}}$ : There is a significant relation between organizational burnout and job performance of technical staff.

$\mathbf{H}_{\mathbf{1 f}}$ : There is a significant relation between organizational burnout and organizational commitment of technical staff.

$\mathbf{H}_{1 \mathbf{g}}$ : There is a significant relation between organizational commitment and job performance of technical staff.

Hypotheses Intended for Engineers;

$\mathbf{H}_{\mathbf{1 j}}$ : There is a significant relation between organizational burnout and job performance of engineers.

$\mathbf{H}_{\mathbf{1 k}}$ : There is a significant relation between organizational burnout and organizational commitment of engineers.

$\mathbf{H}_{1 \mathbf{m}}$ : There is a significant relation between organizational commitment and job performance of engineers.

Difference Hypotheses;

$\mathbf{H}_{\mathbf{1 a}}$ : There is a significant difference between working places and job performance.

$\mathbf{H}_{\mathbf{1 b}}$ : There is a significant difference between working position and job performance.

$\mathbf{H}_{\mathbf{1 c}}$ : There is a significant difference between working location and job performance.

$\mathbf{H}_{\mathbf{1 d}}$ : There is a significant difference between working application and job performance.

$\mathbf{H}_{1 \mathbf{1}}$ : There is a significant difference between working places and organizational burnout.

$\mathbf{H}_{\mathbf{1 f}}$ : There is a significant difference between working location and organizational burnout.

$\mathbf{H}_{1 \mathbf{g}}$ : There is a significant difference between working application and organizational burnout.

$\mathbf{H}_{\mathbf{1 h}}$ : There is a significant difference between working position and organizational burnout.

\subsection{Analysis of Data}

SPSS 20.0 (Statistical Package for Social Sciences) program was used for the statistical analyses, while evaluating the findings obtained in the study. Reliability analysis was carried out for the determination of research data's reliability. For the determination of the effects and the direction of the relation between variables, Correlation and Regression Analyses, and for the determination of the differences between variables, one-way analysis and independent-samples T-test were used in the study.

\subsubsection{Reliability Analysis}

Alpha coefficient (cranbach's alpha) was used for testing the reliabilities of the scales used in the research. The alpha coefficient was found as 0.851 in the result of the reliability analysis.

\subsubsection{Correlation Analysis}

Pearson Correlation Coefficient ( $\mathrm{r}$ ) is used in scaling of direction and strength of a linear relationship between two variables. There are three working positions in the study, which are casual worker, technical staff and engineer. Differentiated correlation analysis according to each working positions is as below.

In the result of the correlation analysis performed; a relation between organizational burnout and job performance for casual workers was found at moderate level $(r=0.597)$, for technical staff at moderate level $(r=$ $0.582)$ and for engineers at high level $(r=0.765)$ of significance. A relation between organizational burnout and organizational commitment for workers was found at low level $(r=0.132)$, and for engineers at low level $(r=$ 0.295) of significance. And for technical staff, any significant relation was not found between organizational burnout and organizational commitment (Sig. > 0.05). In addition, any significant relation was not found between organizational commitment and job performances for casual workers, technical staff and engineers (Sig. > 0.05) (Table 2).

\subsubsection{Regression Analysis}

Regression analysis is a statistical analysis that evaluates the effect of one or more independent variables on a 
dependent variable. There are three working positions in the research, which are casual worker, technical staff and engineer. The differentiated regression analyses according to each working position were stated in the table below.

The statistical significance value of $\mathrm{F}$, which takes part in ANOVA table, must be under $0.05(\mathrm{p}<0.05)$ for regression model to be statistically effective. Accordingly, it is understood that the regression analyses to be established in the research were statistically significant (Table 3).

According to the data in Table 3, the values that job performance may take for casual workers, technical staff and engineers can be formulated as below;

(Casual Worker) "Job Performance $=9.345-(0.457 \times$ Organizational Burnout $)$ "

(Technical Staff) "Job Performance $=10.336-(0.423 \times$ Organizational Burnout $)$ "

(Engineer) "Job Performance $=6.111-(0.613 \times$ Organizational Burnout $)$ "

In the model, it is understood that 1 unit of increase in the organizational burnout level of casual workers resulted in 0.457 unit of decrease in their job performance, 1 unit of increase in the organizational burnout level of technical staff resulted in 0.423 unit of decrease in their job performance, and 1 unit of increase in the organizational burnout level of engineers resulted in 0.613 unit of decrease in their job performance.

\subsubsection{One-Way Analysis}

One-way ANOVA test is used for testing the hypotheses in relation to whether differences between the averages of two or more groups are significant or not.

According to Table 4, while the job performances of the workers in Amasra Enterprise are at the top level (25.4690), the job performances of the workers in Armutçuk Enterprise are at the lowest level (23.4237). According to the result of the $\mathrm{F}$ test performed at $95 \%$ of confidence level, the significance value for job performance was found as $\mathrm{p}=0.012<0.05$. Hereunder, the job performances show a significant difference according to working places.

Table 2. Correlation table.

\begin{tabular}{|c|c|c|c|c|c|c|c|c|c|}
\hline & \multicolumn{3}{|c|}{ Casual Worker } & \multicolumn{3}{|c|}{ Technical Staff } & \multicolumn{3}{|c|}{ Engineer } \\
\hline & (1) & (2) & (3) & (1) & (2) & (3) & (1) & $(2)$ & (3) \\
\hline $\begin{array}{c}\text { Organizational } \\
\text { Burnout (1) }\end{array}$ & 1 & & & 1 & & & 1 & & \\
\hline \multirow{2}{*}{$\begin{array}{l}\text { Organizational } \\
\text { Commitment (2) }\end{array}$} & 0.132 & \multirow{2}{*}{1} & & 0.057 & \multirow[b]{2}{*}{1} & & -0.295 & \multirow[b]{2}{*}{1} & \\
\hline & 0.000 & & & 0.560 & & & 0.022 & & \\
\hline \multirow{2}{*}{ Job Performance (3) } & -0.597 & 0.047 & \multirow{2}{*}{1} & -0.582 & 0.026 & \multirow{2}{*}{1} & -0.765 & -0.198 & \multirow{2}{*}{1} \\
\hline & 0.000 & 0.121 & & 0.000 & 0.790 & & 0.000 & 0.130 & \\
\hline
\end{tabular}

Table 3. Regression table.

\begin{tabular}{|c|c|c|c|c|}
\hline & & Casual Worker & Technical Staff & Engineer \\
\hline \multirow{2}{*}{ ANOVA } & $\mathrm{F}$ & 592.376 & 54.188 & 81.637 \\
\hline & $\mathrm{p}$ & 0.000 & 0.000 & 0.000 \\
\hline \multirow{3}{*}{$\begin{array}{c}\text { Model } \\
\text { Abstract }\end{array}$} & $\mathrm{r}$ & 0.597 & 0.582 & 0.765 \\
\hline & r Square & 0.357 & 0.338 & 0.585 \\
\hline & Adjusted r Square & 0.356 & 0.332 & 0.557 \\
\hline \multirow{3}{*}{ Regression } & $\beta$ & -0.457 & 0.423 & -0.613 \\
\hline & $\mathrm{T}$ & -24.339 & -7.361 & -9.035 \\
\hline & $\mathrm{p}$ & 0.000 & 0.000 & 0.000 \\
\hline
\end{tabular}


According to Table 5, while the job performances of the engineers are at the top level (25.8833), the job performances of the technical staff are at the lowest level (23.6759). According to the result of the F test performed at $95 \%$ of confidence level, the significance value of job performance was found as $p=0.172>0.05$. Hereunder, the job performances do not show a significant difference according to working positions.

According to Table 6, while the organizational burnout of the employees in Amasra Enterprise is at the top level (36.0000), the organizational burnout of the employees in Armutçuk Enterprise is at the lowest level (31.6949). According to the result of the $\mathrm{F}$ test performed at 95\% of confidence level, the significance value for job performance was found as $p=0.002<0.05$. Hereunder, the organizational burnout levels of workers show a significant difference according to working places.

According to Table 7, while the organizational burnout level of casual workers is at the top level (32.9981),

Table 4. One-way analysis intended for $\mathrm{H}_{1 \mathrm{a}}$ hypothesis.

\begin{tabular}{ccccccc}
\hline & N & Mean & Std. Deviation & Std. Error & F & Sig. \\
\hline G. Directorate & 128 & 25.2266 & 6.62162 & 0.58527 & & \\
Armutçuk & 118 & 23.4237 & 8.19047 & 0.75399 & & \\
Amasra & 113 & 25.4690 & 8.19306 & 0.77074 & & 0.012 \\
Üzülmez & 349 & 23.4355 & 7.22181 & 0.38657 & 2.927 & 0.44388 \\
Karadon & 261 & 24.8429 & 7.17114 & & 0.42298 \\
Kozlu & 269 & 24.9182 & 6.93741 & & \\
Total & 1238 & 24.4241 & 7.31165 & 0.20780 & & \\
\hline
\end{tabular}

Table 5. One-way analysis intended for $\mathrm{H}_{1 \mathrm{~b}}$ hypothesis.

\begin{tabular}{cccccc}
\hline & N & Mean & Std. Deviation & Std. Error & F \\
\hline Casual Worker & 1070 & 24.4178 & 7.35536 & 0.22486 & \\
Technical Staff & 108 & 23.6759 & 6.76001 & 0.65048 & 0.95346 \\
Engineer & 60 & 25.8833 & 7.38549 & 0.20780 & \\
Total & 1238 & 24.4241 & 7.31165 & \\
\hline
\end{tabular}

Table 6. One-way analysis intended for $\mathrm{H}_{1 \mathrm{e}}$ hypothesis.

\begin{tabular}{cccccc} 
& $\mathbf{N}$ & Mean & Std. Deviation & Std. Error & Fig. \\
\hline G. Directorate & 128 & 32.5703 & 8.57086 & 0.75756 \\
Armutçuk & 118 & 31.6949 & 10.07452 & 0.92743 \\
Amasra & 113 & 36.0000 & 8.90225 & 0.83745 & 3.935 \\
Üzülmez & 349 & 31.9026 & 10.93485 & 0.58533 & 0.002 \\
Karadon & 261 & 32.5594 & 8.66610 & 0.53642 & 0.53176 \\
Kozlu & 269 & 33.6171 & 8.72156 & 0.27210 \\
Total & 1238 & 32.8368 & 9.57399 & \\
\hline
\end{tabular}

Table 7. One-way analysis intended for $\mathrm{H}_{1 \mathrm{f}}$ hypothesis.

\begin{tabular}{cccccc}
\hline & N & Mean & Std. Deviation & Std. Error & Sig. \\
\hline Casual Worker & 1070 & 32.9981 & 9.61835 & 0.29404 \\
Technical Staff & 108 & 31.5648 & 9.30307 & 0.89519 & 1.218 \\
Engineer & 60 & 32.2500 & 9.21058 & 1.18908 & 0.296 \\
Total & 1238 & 32.8368 & 9.57399 & 0.27210 \\
\hline
\end{tabular}


the organizational burnout level of the technical staff is at the lowest level (31.5648). According to the result of the $\mathrm{F}$ test performed at $95 \%$ of confidence level, the significance value of job performance was found as $\mathrm{p}=$ $0.296>0.05$. Hereunder, the burnout levels of workers do not show a significant difference according to their working positions.

\subsubsection{Independent-Samples T-Tests}

Independent-samples T-test is a method used in the comparison of the measurements of both groups. The data related to the test of the $\mathrm{H}_{1 \mathrm{c}}, \mathrm{H}_{1 \mathrm{~d}}, \mathrm{H}_{1 \mathrm{~g}}$ and $\mathrm{H}_{1 \mathrm{~h}}$ hypotheses through this method is as below.

In Table 8, in the result of the test performed on $\mathrm{H}_{1 \mathrm{c}}, \mathrm{H}_{1 \mathrm{~d}}$, and $\mathrm{H}_{1 \mathrm{~h}}$ hypotheses at $95 \%$ confidence level, the significance levels of these hypotheses were found bigger than 0.05 and the significance level of $\mathrm{H}_{1 \mathrm{~g}}$ hypothesis was found under 0.05 . Accordingly, the job performances of blue-collar workers working within the facilities of TTK do not show a significant difference according to working locations (underground or above ground) and working practice (in-shift or shiftless). And the organizational burnout levels of the blue-collar workers working within the facilities of TTK show a significant difference according to their working locations (underground or above ground), however they do not show a significant difference according to working practice (in-shift or shiftless).

\section{Conclusions}

The aims of our study, with the theme of the correlation analytic of blue-collar workers' organizational levels in coal mining, are determining the organizational burnout, job performance and organizational commitment levels of the employees working in coal mining and revealing the interactions of these levels. In the result of the quota sampling in Turkish Hard Coal Enterprise depending upon this purpose, a research intended for 1238 blue-collar workers was performed.

98.3\% of the blue-collar workers who involved in the study were men, and $1.7 \%$ was women. When their age distributions were analyzed, it was determined that a majority of $42.2 \%$ of the sampling were at the age range of 31 - 40, 26.7\% were 40 and above, and 31.1\% were under the age of 30. These statistics show that the blue-collar workers in the coal enterprise analyzed were young and in a dynamic structure. This assessment is particularly an important factor for the burnout analysis of employees.

When the educational backgrounds of the blue-collar workers were analyzed, it was seen that only $9.9 \%$ of 1238 employees were higher education graduates, $40.2 \%$ were primary education graduates, and $49.8 \%$ were high school graduates. The lowness of educational background complicates the comprehension of plans and policies and consciousness raising in coal mining management. This also speeds up the transaction from formal into informal structure in management and distorts the aims and targets requested.

When work practice was analyzed, it was determined that $68.9 \%$ of 1238 workers worked in-shift and 31.1\% worked shiftless. And the work locations of these workers were $76 \%$ underground and $24 \%$ above ground. Considering their working positions, $86.4 \%$ of the employees stated that they were casual workers, $8.7 \%$ were technical staff and $4.8 \%$ were engineers. These statistics strengthened the aim of the study. Employees working below ground, who provide the main production, to have a share of $76 \%$ in the research enables a better analysis of results and suggestions.

In the result of the analysis of organizational burnout, one of the variables in the study, with regards to working places, it was determined the highest and lowest organizational burnout levels were in Amasra and Ar-

Table 8. Independent T-test related to $\mathrm{H}_{1 \mathrm{c}}$ hypothesis.

\begin{tabular}{|c|c|c|c|c|c|c|c|}
\hline & \multicolumn{2}{|c|}{$\begin{array}{c}\text { Levene's Test for Equality of } \\
\text { Variances }\end{array}$} & \multicolumn{5}{|c|}{ T-Test for Equality of Means } \\
\hline & $\mathbf{F}$ & Sig. & $\mathbf{t}$ & df & Sig. (2-tailed) & Mean Difference & $\begin{array}{l}\text { Std. Error } \\
\text { Difference }\end{array}$ \\
\hline $\mathbf{H}_{1 \mathrm{c}}$ & 0.686 & 0.408 & 0.291 & 1236 & 0.771 & 0.14153 & 0.48681 \\
\hline $\mathbf{H}_{1 \mathrm{~d}}$ & 1.088 & 0.297 & -1.670 & 1236 & 0.095 & -0.74917 & 0.44860 \\
\hline $\mathbf{H}_{1 \mathrm{~g}}$ & 0.002 & 0.961 & 2.309 & 1236 & 0.021 & 1.46862 & 0.63609 \\
\hline $\mathbf{H}_{1 \mathrm{~h}}$ & 2.157 & 0.142 & 1.406 & 1236 & 0.160 & 0.82625 & 0.58759 \\
\hline
\end{tabular}


mutçuk Enterprises respectively. And when the job performance criterion is analyzed, it was determined again that the establishments with highest and lowest job performances were Amasra and Armutçuk Enterprises respectively. Even if this creates a contrast perception, it is a usual case as it epitomizes in literature researches. The relation between organizational burnout and job performance is not always inversely proportional. The direction of this relation depends upon the structure of the connection between employee and organization. In the research carried out, it was seen that $25.9 \%$ of the blue-collar workers went to work reluctantly, $24 \%$ did not have sense of belonging to the organization, and only $16.9 \%$ have the intent of leaving the job. With this, the direct proportion between job performance and organizational burnout can be stated clearly. The job performances of the blue-collar workers within the body of TTK have an impact on their organizational burnout levels. The performance policies have an important role in the development of such a situation. Here, it is seen that the reasons for burnout of the workers do not result from the formation of cowed individuals. The above state of burnout is related to the work tempo of the employees and the heaviness of the job worked. $43.5 \%$ of the blue-collar workers to mention that they were affected by the working conditions directly also support this result.

Another data evaluated in the research is the tendency to teamwork. $72.3 \%$ of the blue-collar workers told that they could work in conformity with their workfellows. This is statistically positive with regards to aims and targets of the organization. Employees under heavy working conditions not to spend their energy to social polarization affects positively to the performance requested. However, 66\% of employees to be afraid of getting healthwise harm were determined as a static factor that slows down the workflow with its negative effect upon working psychologies of the employees.

In the result of discriminant analyses performed within the scope of the research, it was determined that the job performances of the blue-collar workers varied according to their working places, but did not vary according to their working positions (casual worker, technical staff or engineer), working locations (underground or above ground) and working practice (in-shift or shiftless). In addition, it was determined that organizational burnout levels of the employees varied according to working places and working locations (underground or above ground), but did not vary according to working position (casual worker, technical staff or engineer) and working practice (in-shift or shiftless).

In the result of the researches carried out, a relation was not determined between organizational commitment and burnout and job performance. Considering that $45.9 \%$ of 1283 blue-collar workers felt sense of belonging to the establishment they worked, it was determined that there was organizational commitment in the establishment, however, this commitment did not decrease with the organizational burnout or the job performance did not increase with the increase in commitment. This shows that the employees of the establishment have a sense of belonging independent from the organizational climate. The reason for this may be it is the best job opportunity in the region considering the educational backgrounds of people, as well as the emotional commitment of a generation grew with mining. No matter its different reasons, employees to have a commitment, independent of organizational climate, are important for the establishment. Particularly, the factors that take people off cynicism have a great influence on the organizational commitment. So, a decrease in the organizational commitment triggers the intent of leaving the job. The constant cease of employment and new worker recruitments both hinder the production and create problems with regards to job security. While training and adaptation of a new worker cause a decrease in production, the hazard dimension that can be caused by an inexperienced worker in mine is unclear. Considering in this respect, the existence of an imperative and/or emotional commitment is seen as a positive situation for the operation of the organization. However, considering with regards to performance, it was seen as a negative situation, the type of commitment felt not to affect the performance.

In the result of the analysis carried out, it was determined that the establishments with the highest and lowest job performance and organizational commitment were the same establishments. As stated above, there is a different relation between the organizational burnout and job performances of the blue-collar workers pursuant to the organizational commitment model. As it is seen in the analysis results, as the organizational burnout levels of employees increasing, their performances decrease. Here, there are two points to be considered. The first one is the burnout developing in parallel with employees to feel tired and daunted as a result of high performance. The second one is the decline in the performances of the employees depending upon the matter of burnout that involves reluctance, ceasing of employment and losing heart because of the psychical problems developed in their working psychologies. In the study performed, it was determined that both of these cases realized for the blue- collar workers working in hard coal enterprise. 


\section{Further Study}

In this study, the relations among organizational burnout, job performance and commitment levels were tried to be determined for blue-collar workers in coal mining. However, a comparison for organizational level could not be made due to nonbeing of another study with equivalent content in the literature. So making an international comparison intended for employees in coal mining will be possible and the organizational climates of mines in different countries and the organizational levels of employees will be able to be correlated with researches that will be carried out in coalmines in the future to involve sufficient organizational magnitude and with the analysis of data in detail.

\section{References}

[1] Hard Coal Report (2010) Chamber of Mining Engineers of Turkey. http://www.maden.org.tr/resimler/ekler/0f88bfbf93f5078 ek.pdf

[2] TWBG (2007) Coal Mining and Production. http://www.ifc.org/wps/wcm/connect/79a98080488552b5ac5cfe6a6515bb18/coal_PPAH.pdf?MOD=AJPE $\underline{\mathrm{RES}}$

[3] TTK (2013) Hard Coal Sector Report. http://www.enerji.gov.tr/File/?path=ROOT\%2F1\%2FDocuments\%2FSayfalar\%2F2012+Y\%C4\%B1l\%C4\%B1+ Sekt\%C3\%B6r+Raporu+(TTK).pdf

[4] Ünalan, G. (2003) General Evaluation of Energy Resources of Turkey. Geotogicat Engineering Journal, 27, 17-44.

[5] Korkmaz, O. (2011) The Relationship between Work Accident and Productivity: A Case Study in Turkish Hard Coal Enterprise. Journal of Yasar University, 23, 3805-3813.

[6] Dargah, G.D. and Estalkhbijari, Z.P. (2012) The Relationship between the Big Five Personality Factors and Job Burnout. International Journal of Asian Social Science, 11, 1842-1850.

[7] Kraft, U. (2006) The Burned Out. Scientific American Mind, June/July, 28-33.

[8] Maslach, C. and Jackson, S.E. (1981) The Measurement of Experienced Burnout. Journal of Occupatıonal Behaviour, 2, 99-113. http://dx.doi.org/10.1002/job.4030020205

[9] Sarros, J.C. and Densten, I.L. (1989) Undergraduate Student Stress and Coping Strategies. Higher Education Research and Development, 8, 47-57. http://dx.doi.org/10.1080/0729436890080105

[10] Campagne, D.M. (2012) When Therapists Run out of Steam: Professİonal Boredom or Burnout? Revista de Psicopatología y Psicología Clínica, 17, 75-85. http://dx.doi.org/10.5944/rppc.vol.17.num.1.2012.10370

[11] Pines, A.M. and Aronson, E. (1988) Career Bumout: Causes and Cures. Free Press, New York.

[12] Enzmann, D., Schaufeli, W.B., Janssen, P. and Rozeman, A. (1998) Dimensionality and Validity of the Burnout Measure. Journal of Occupational and Organizational Psychology, 71, 331-351. http://dx.doi.org/10.1111/j.2044-8325.1998.tb00680.x

[13] Katyal, S. (2013) Burnout among Nurses Working in Government and Private Hospitals. Studies on Home and Community Science, 7, 83-85.

[14] Nagar, K. (2012) Organizational Commitment and Job Satisfaction among Teachers during Times of Burnout. Vlkalpa, 37, 43-60.

[15] Fiksenbaum, L., Marjanovic, Z., Greenglass, E.R. and Coffey, S. (2006) Emotional Exhaustion and State Anger in Nurses Who Worked during the SARS Outbreak: The Role of Perceived Threat and Organizational Support. Canadian Journal of Community Mental Health, 25, 89-103. http://dx.doi.org/10.7870/cjcmh-2006-0015

[16] Paris, M. and Huge, M. (2010) Burnout in the Mental Health Workforce: A Review. The Journal of Behavioral Health Services \& Research, 37, 519-528. http://dx.doi.org/10.1007/s11414-009-9202-2

[17] Salanova, M., Llorens, S., García-Renedo, M., Burriel, R., BresÓ, E. and Schaufeli, W.B. (2005) Towards a Four-Dimensional Model of Burnout: A Multigroup Factor-Analytic Study Including Depersonalization and Cynicism. Educational and Psychological Measurement, 65, 807-819. http://dx.doi.org/10.1177/0013164405275662

[18] Ullah, S. (2012) Behavioral Troubles for the Newcomer Doctors in the Public Sector Hospitals of Pakistan. Asian Journal of Health, 2, 1-15. http://dx.doi.org/10.7828/ajoh.v2i1.115

[19] Principal, P. and Chhabra, U. (2012) A Study of Burnout among Secondary School Teachers in Relation to Their Emotional Intelligence and Organizational Commitment. International Journal of Computer Science and Communication Engineering, 2, 54-60.

[20] Schaufeli, W.B. and Greenglass, E.R. (2001) Introduction to Special Issue on Burnout and Health. Psychology and Health, 


\section{6, 501-510. http://dx.doi.org/10.1080/08870440108405523}

[21] Emmerik, H.V., Jawahar, I.M. and Stone, T.H. (2005) Associations among Altruism, Burnout Dimensions and Organizational Citizenship Behaviour. Work \& Stress, 19, 93-100. http://dx.doi.org/10.1080/02678370500046283

[22] Dorman, J. (2003) Testing a Model for Teacher Burnout. Australian Journal of Educational \& Developmental Psychology, 3, 35-47.

[23] Knani, M. and Fournier, P.S. (2013) Burnout, Job Characteristics, and Intent to Leave: Does Work Experience Have Any Effect. Journal of Emerging Trends in Economics and Management Sciences, 4, 403-408.

[24] Özler, D.E., Atalay C.G. and Şahin, M.D. (2010) Örgütlerde Sinizm Güvensizlikle Mi Bulaşır? Organizasyon ve Yönetim Bilimleri Dergisi, 2, 47-57.

[25] McShane, S.L. and Von Glinow, M.A. (2003) Organizational Behaviour. International Edition, McGraw-Hill Education, New York.

[26] Siğri, Ü. and Basım, N. (2006) İş Görenlerin İş Doyumu İle Örgütsel Bağl1lık Düzeylerinin Analizi: Kamu ve Özel Sektörde Karşılaştırmalı Bir Araştırma. Selçuk Üniversitesi İktisadi ve İdari Bilimler Fakültesi Sosyal ve Ekonomik Araştırmalar Dergisi, 12, 131-154.

[27] Cook, J. and Wall, T. (1980) New Work Attitude Measures of Trust, Organizational Commitment and Personal Need Non-Fulfilment. Journal of Occupational Psychology, 53, 39-52.http://dx.doi.org/10.1111/j.2044-8325.1980.tb00005.x

[28] Meyer, J.P., Stanley, D.J., Herscovitch, L. and Topolnytsky, L. (2002) Affective, Continuance, and Normative Commitment to the Organization: A Meta-Analysis of Antecedents, Correlates, and Consequences. Journal of Vocational Behavior, 61, 20-52. http://dx.doi.org/10.1006/jvbe.2001.1842

[29] O’Driscoll, M.P. and Donna, M.R. (1999) Perceived Organisational Support, Satisfaction with Rewards, and Employee Job Involvement and Organisational Commitment. Applied Psychology: An International Review, 48, 197-209.

[30] Commeiras, N. and Fournier, C. (2001) Critical Evaluation of Porter et al.'s Organizational Commitment Questionnaire: Implications for Researchers. Journal of Personal Selling \& Sales Management, 17, 239-245.

[31] Chang, E. (1999) Career Commitment as a Complex Moderator of Organizational Commitment and Turnover Intention. Human Relations, 52, 1257-1278. http://dx.doi.org/10.1177/001872679905201002

[32] Fu, F.Q., Bolander, W. and Jones, E. (2009) Managing the Drivers of Organizational Commitment and Salesperson Effort: An Application of Meyer and Allen's Three-Component Model. Journal of Marketing Theory and Practice, 17, 335-350. http://dx.doi.org/10.2753/MTP1069-6679170403

[33] Karim, N.H. and Noor, N.H. (2006) Evaluating The Psychometric Properties of Allen and Meyer's Organizational Commitment Scale: A Cross Cultural Application among Malaysian Academic Librarians. Malaysian Journal of Library \& Information Science, 11, 89-101.

[34] Prabhakar, G.V. and Ram, P. (2011) Antecedent HRM Practices for Organizational Commitment. International Journal of Business and Social Science, 2, 55-62.

[35] Allen, N.J. and Meyer, J.P. (1990) The Measurement and Antecedents of Affective, Continuance and Normative Commitment to the Organization. Journal of Occupational Psychology, 63, 1-18. http://dx.doi.org/10.1111/j.2044-8325.1990.tb00506.x

[36] Scullen, S.E., Mount, M.K. and Goff, M. (2000) Understanding the Latent Structure of Job Performance Eatings. Journal of Applied Psychology, 85, 54-60. http://dx.doi.org/10.1037/0021-9010.85.6.956

[37] Shamsuddin, N. and Rahman, R.A. (2014) The Relationship between Emotional Intelligence and Job Performance of Call Centre Agents. Procedia-Social and Behavioral Sciences, 129, 75-81. http://dx.doi.org/10.1016/j.sbspro.2014.03.650

[38] Yozgat, U., Yurtkoru, S. and Bilginoğlu, E. (2013) Job Stress and Job Performance among Employees in Public Sector in Istanbul: Examining the Moderating Role of Emotional Intelligence. Procedia-Social and Behavioral Sciences, 75, 518-524. http://dx.doi.org/10.1016/j.sbspro.2013.04.056

[39] Borman, W.C. and Motowidlo, S.J. (1993) Expanding the Criterion Domain to Include Elements of Contextual Performance. In: Schmitt, N. and Borman, W.C., Eds., Personnel Selection in Organizations, Wiley, New York, 71-98.

[40] Jankingthong, K. and Rurkkhum, S. (2012) Factors Affecting Job Performance: A Review of Literature. Silpakorn University Journal of Social Sciences, Humanities, and Arts, 12, 115-127.

[41] Muchhal, D.S. (2014) HR Practices and Job Performance. Journal of Humanities and Social Science, 19, 55-61.

[42] Yun, S., Takeuchi, R. and Liu, W. (2007) Employee Self-Enhancement Motives and Job Performance Behaviors: Investigating the Moderating Effects of Employee Role Ambiguity and Managerial Perceptions of Employee Commitment. Journal of Applied Psychology, 92, 745-756. http://dx.doi.org/10.1037/0021-9010.92.3.745

[43] Scotter, J.R.V., Motowidlo, S.J. and Cross, T.C. (2000) Effects of Task Perfonnance and Contextual Performance on Systemic Rewards. Journal of Applied Psychology, 85, 526-535. http://dx.doi.org/10.1037/0021-9010.85.4.526 
[44] Borman, W.C. and Motowidlo, S.J. (1997) Task Performance and Contextual Performance: The Meaning for Personnel Selection Research. Human Performance, 10, 99-109. http://dx.doi.org/10.1207/s15327043hup1002_3

[45] Kahya, E. (2007) The Effects of Job Characteristics and Working Condition on Job Performance. International Journal on Industrial Ergonomics, 37, 515-523. http://dx.doi.org/10.1016/j.ergon.2007.02.006

[46] Mansi, G. and Levy, Y. (2013) Do Instant Messaging İnterruptions Help or Hinder Knowledge Workers’ Task Performance? International Journal of Information Management, 33, 591-596. http://dx.doi.org/10.1016/j.ijinfomgt.2013.01.011

[47] Rahman, A. and Badayai, A. (2012) Theoretical Framework and Analytical Discussion on Uncongenial Physical Workplace Environment and Job Performance among Workers in Industrial Sectors. Procedia-Social and Behavioral Sciences, 42, 486-495. http://dx.doi.org/10.1016/j.sbspro.2012.04.214

[48] Mclaggan, E., Bezuidenhout, A. and Botha, C.T. (2013) Leadership Style and Organisational Commitment in the Mining Industry in Mpumalanga. SA Journal of Human Resource Management, 11, 483-492. http://dx.doi.org/10.4102/sajhrm.v11i1.483

[49] Kowalski, K.M. and Podlesny, A. (2000) The Effects of Disaster on Workers: A Study of Burnout in Investigators of Serious Accidents and Fatalities in the US Mining Industry. National Institute for Occupational Safety and Health, Pennsylvania.

[50] Talachi, R.K. and Gorji, M.B. (2013) Job Burnout and Job Satisfaction among Industry, Mine and Trade Organization Employees: A Questionnaire Survey. International Journal of Academic Research in Business and Social Sciences, 3 , 21-41. http://dx.doi.org/10.6007/IJARBSS/v3-i7/7

[51] Yusuf, R.M., Hamid, N., Eliyana, A., Bahri, S. and Sudarisman, A. (2012) The Antecedents of Employee's Performance: Case Study of Nickel Mining’s Company, Indonesia. Journal of Business and Managements, 2, 22-28.

[52] Meyer, J.P., Paunonen, S.V., Gellaty, I.R., Goffin, R.D. and Jackson, D.N. (1989) Organizational Commitment and Job Performance: It's the Nature of the Commitment That Counts. Journal of Applied Psychology, 74, 152-156. http://dx.doi.org/10.1037/0021-9010.74.1.152

[53] Salehi, M. and Gholtash, A. (2011) The Relationship between Job Satisfaction, Job Burnout and Organizational Commitment with the Organizational Citizenship Behavior among Members of Faculty in the Islamic Azad University-First District Branches, in Order to Provide the Appropriate Model. Procedia Social and Behavior Sciences, 15, 306-310. http://dx.doi.org/10.1016/j.sbspro.2011.03.091

[54] Güneş, İ., Bayraktaroğlu, S. and Kutanis, R.Ö. (2009) A Relationship on Organizational Commitment of Emploless and Burnout Level: Sample from a State University, Suleyman Demirel University. The Journal of Faculty of Economics and Administrative Sciences, 143, 481-497.

[55] Marmaya, N.H., Zawawi, N., Hitam, M. and Jody, J.M. (2011) Organizational Commitment and Job Burnout among Employees in Malaysia. International Conference on Business and Economics Research, 1, 185-197.

[56] Cropanzano, R., Rupp, D.E. and Byrne, Z.S. (2003) The Relationship of Emotional Exhaustion to Work Attitudes, Job Performance, and Organizational Citizenship Behaviors. Journal of Applied Psychology, 88, 160-169. http://dx.doi.org/10.1037/0021-9010.88.1.160

[57] Yiing, L.H. and Ahmad, K.Z.B. (2009) The Moderating Effects of Organizational Culture on the Relationships between Leadership Behaviour and Organizational Commitment and between Organizational Commitment and Job Satisfaction and Performance. Leadership \& Organization Development Journal, 30, 53-86. http://dx.doi.org/10.1108/01437730910927106 
Scientific Research Publishing (SCIRP) is one of the largest Open Access journal publishers. It is currently publishing more than 200 open access, online, peer-reviewed journals covering a wide range of academic disciplines. SCIRP serves the worldwide academic communities and contributes to the progress and application of science with its publication.

Other selected journals from SCIRP are listed as below. Submit your manuscript to us via either submit@scirp.org or Online Submission Portal.
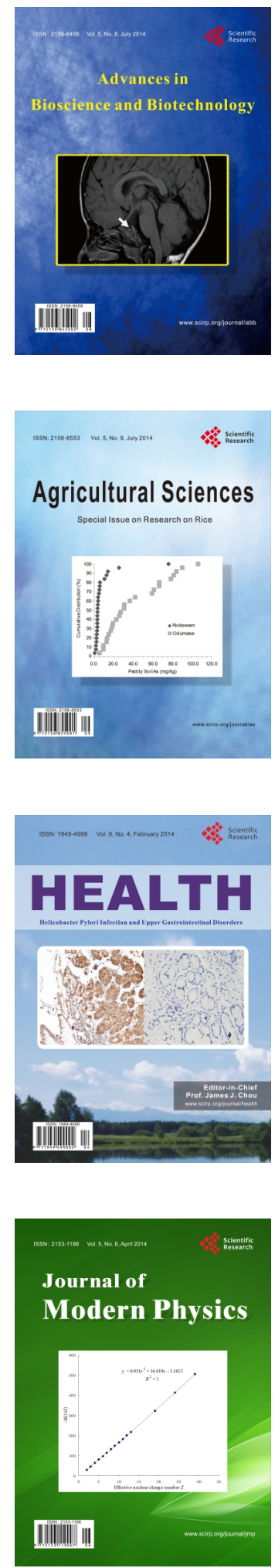
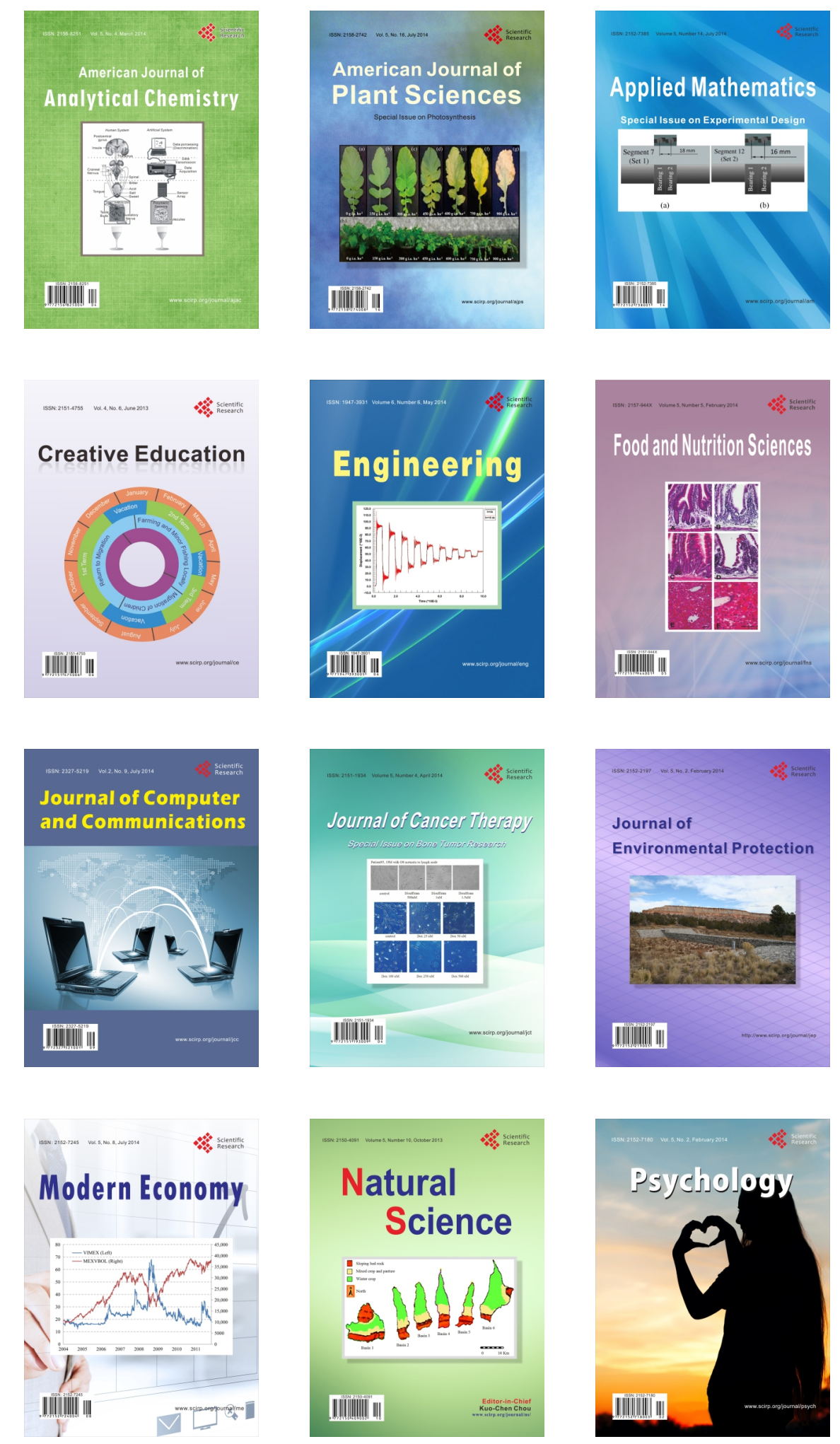